\title{
Peningkatan kinerja guru dalam pembelajaran melalui supervisi edukatif kolaboratif secara periodik di SDN 3 Palam Kota Banjarbaru
}

\section{Improving teacher performance in learning through periodic collaborative educational supervision at Elementary School 3 Palam, Banjarbaru City}

\author{
Kesuma Dewi ${ }^{1}$ \\ ${ }^{1}$ SDN 3 Palam Kota Banjarbaru \\ Email: kesumadewi19031970@gmail.com ${ }^{1}$
}

\section{INFO ARTIKEL}

Diterima : 30 April 2021

Disetujui : 27 Mei 2021

Tersedia secara Online Mei 2021

\author{
Alamat Korespondensi: \\ Kesuma Dewi \\ SDN 3 Palam Kota Banjarbaru \\ Jl. Purnawirawan,Guntungmanggis, \\ Landasan Ulin, Provinsi Kalimantan \\ Selatan \\ E-mail: \\ kesumadewi19031970@gmail.com
}

\begin{abstract}
ABSTRAK
Seorang guru harus selalu meningkatkan kemampuan profesionalnya, pengetahuan, sikap dan keterampilannya secara terus-menerus sesuai perkembangan ilmu pengetahuan dan teknologi termasuk paradigma baru pendidikan. Tujuan penelitian ini adalah mendeskripsikan langkah-langkah supervisi edukatif kolaboratif secara periodik dalam melaksanakan pembelajaran, menilai prestasi belajar, melaksanakan tindak lanjut penilaian prestasi belajar siswa, menyusun rencana pembelajaran. Penelitian ini merupakan penelitian tindakan maka pelaksanakan ini dilaksanakan secara siklus. Pelaksanaannya selama dua siklus. Siklus-siklus itu merupakan rangkaian yang saling berkelanjutan, maksudnya siklus kedua merupakan kelanjutan dari siklus pertama. Setiap siklusnya selalu ada persiapan tindakan, pelaksanaan tindakan, pemantauan, evaluasi, dan refleksi. Pelaksanaan supervisi edukatif kolaboratif secara periodik dapat meningkatkan kinerja guru dalam melaksanakan tindak lanjut hasil penilaian prestasi belajar siswa dengan langkah-langkah sebagai berikut. (1) Peneliti dan guru bersama-sama membuat program tindak lanjut hasil penilaian, (2) Peneliti memberi contoh pelaksanaan tindak lanjut, yang akhirnya dilanjutkan oleh guru dalam pelaksanaan yang sebenarnya, (3) Peneliti mengajak diskusi pada guru yang telah membuat, melaksanakan, dan menganalis program tindak lanjut. Kesimpulan dari penelitian ini adalah, peningkatan kinerja guru baik rencana pembelajaran, pelaksanaan pembelajaran, penilaian hasil belajar, dan pelaksanaan tindak lanjut hasil penilaian siswa ternyata mempengaruhi hasil ujian siswa.
\end{abstract}

Kata kunci: Peningkatan, Kinerja Guru, Supervisi.

A teacher must always improve his professional abilities, knowledge, attitudes and skills continuously according to the development of science and technology, including a new paradigm of education. The purpose of this study is to describe the steps for periodic collaborative educational supervision in implementing learning, assessing learning achievement, carrying out follow-up assessments of student learning achievement, compiling learning plans. This research is an action research, so this implementation is carried out in a cycle. The implementation is for two cycles. The cycles are a series that are mutually sustainable, meaning that the second cycle is a continuation of the first cycle. Every cycle there is always action preparation, action implementation, monitoring, evaluation, and reflection. The periodic implementation of collaborative educational supervision can improve teacher performance in carrying out follow-up results of student achievement appraisals with the following steps. (1) The researcher 
and the teacher together make a follow-up program for the results of the assessment, (2) The researcher gives an example of the follow-up implementation, which is finally followed by the teacher in the actual implementation, (3) The researcher invites discussion to the teacher who has made, implemented, and analyzing follow-up programs. The conclusion of this study is that the improvement of teacher performance both in the lesson plans, the implementation of learning, the assessment of learning outcomes, and the implementation of follow-up on the results of student assessments in fact affect the results of student exams.

Keywords: Improvement, Teacher Performance, Supervision.

\section{PENDAHULUAN}

Menurut Undang-Undang Guru pasal 1 ayat 1 (2006:3) guru adalah pendidik profesional dengan tugas utama: mendidik, mengajar, membimbing, mengarahkan, melatih, menilai, dan mengevaluasi peserta didik pada pendidikan anak usia dini jalur pendidikan formal, pendidikan dasar dan pendidikan menengah.

Menurut Syamsuddin (2005:66) ada tiga komponen utama yang saling berkaitan dan memiliki kedudukan strategis dalam kegiatan belajar mengajar. Ketiga komponen tersebut adalah kurikulum, guru, dan pembelajar (siswa). Ketiga komponen itu, guru menduduki posisi sentral sebab peranannya sangat menentukan. Dalam pembelajaran seorang guru harus mampu menerjemahkan nilai-nilai yang terdapat dalam kurikulum secara optimal. Walaupun sistem pembelajaran sekarang sudah tidak theacher center lagi, namun seorang guru tetap memegang peranan yang penting dalam membimbing siswa. Bahkan berdasarkan seorang guru harus mempunyai pengetahuan yang memadai baik di bidang akademik maupun pedagogic (Mashud, 2015). Seorang guru harus selalu meningkatkan kemampuan profesionalnya, pengetahuan, sikap dan keterampilannya secara terus-menerus sesuai perkembangan ilmu pengetahuan dan teknologi termasuk paradigma baru pendidikan.

Untuk mencapai tiga kompetensi tersebut, sekolah harus melaksanakan pembinaan terhadap guru baik melalui workshop, PKG, diskusi dan supervisi edukatif. Hal itu harus dilakukan secara periodik agar kinerja dan wawasan guru bertambah sebab berdasarkan diskusi yang dilakukan guru di SDN 3 Palam, rendahnya kinerja dan wawasan guru diakibatkan (1) rendahnya kesadaran guru untuk belajar, (2) kurangnya kesempatan guru mengikuti pelatihan, baik secara regional maupun nasional, (3) kurang efektifnya PKG, (4) supervisi pendidikan yang bertujuan memperbaiki proses pembelajaran cenderung menitikberatkan pada aspek administrasi.

Untuk memperbaiki kinerja dan wawasan guru dalam pembelajaran di SDN 3 Palam, sekolah melaksanakan penelitian tindakan yang berkaitan dengan permasalahan di atas. Karena keterbatasan peneliti, maka penelitian ini hanya divokuskan pada supervisi edukatif saja sehingga judul penelitian tindakan tersebut adalah "Peningkatan Kinerja Guru dalam Pembelajaran di Kelas Melalui Supervisi Edukatif Kolaboratif secara Periodik".

Karena supervisi edukatif melibatkan supervisor, guru, siswa dan lingkungan maka dalam penelitian tindakan ini, peneliti (kepala sekolah) sebagai pengawas SD bersama semua guru SDN 3 Palam mengidentifikasi masalah pembelajaran. Selanjutkan menentukan langkahlangkah pemecahan masalah. Hasil diskusi diperoleh langkah-langkah pemecahan, yakni: (1) 
mengadakan workshop singkat tentang pembuatan persiapan pembelajaran, pelaksanaan, dan penilaian pembelajaran di sekolah, (2) melaksanakan supervisi edukatif kolaboratif secara periodik dengan menekankan pada pemberian bantuan untuk perbaikan pembelajaran. Tujuan penelitian ini adalah mendeskripsikan langkah-langkah supervisi edukatif kolaboratif secara periodik dalam melaksanakan pembelajaran, menilai prestasi belajar, melaksanakan tindak lanjut penilaian prestasi belajar siswa, menyusun rencana pembelajaran.

Untuk menghindari salah pengertian mengenai istilah yang digunakan dalam penelitian tindakan ini, maka perlu adanya batasan istilah, di antaranya adalah: (1) Peningkatan, menurut KBBI (1885:861) peningkatan adalah proses, perbuatan, cara meningkatkan, (2) Kinerja, menurut KBBI (1885:504) kinerja memiliki tiga makna, yaitu sesuatu yang dicapai, prestasi yang diperlihatkan, kemampuan kerja, (3) Guru adalah orang yang pekerjaannya mengajar, membimbing siswa, (4) Supervisi adalah aktivitas pembinaan yang diharapkan dapat meningkatkan kinerja seseorang, (5) Edukatif adalah bersifat mendidik. Berdasarkan pengertian di atas maka judul penelitian tersebut bisa dijelaskan sebagai berikut: Cara meningkatkan prestasi guru dengan memberi pembinaan dan kerja sama secara terus-menerus berdasarkan pada waktu yang telah ditentukan.

\section{METODE}

Penelitian ini merupakan Penelitian Tindakan Sekolah maka pelaksanakan ini dilaksanakan secara siklus. Pelaksanaannya selama dua siklus. Siklus-siklus itu merupakan rangkaian yang saling berkelanjutan, maksudnya siklus kedua merupakan kelanjutan dari siklus pertama. Setiap siklusnya selalu ada persiapan tindakan, pelaksanaan tindakan, pemantauan dan evaluasi, dan refleksi.

Penelitian ini dilaksanakan di SDN 3 Palam pada tahun pelajaran 2020/2021. Pada tahun itu banyak hasil penelitian yang kurang mengarah pada peningkatan mutu pendidikan. Peneliti mengambil tempat penelitian di SDN 3 Palam karena SD itu adalah SD binaan peneliti. Guru-guru di SDN 3 Palam ada yang Guru Honorer, PNS, dan ijazahnya pun beragam, yakni ada yang berijazah diploma, sarjana, dan pascasarjana. Waktu penelitian adalah pada tahun pelajaran 2020/2021. Selama penelitian tersebut peneliti mengumpulkan data awal, menyusun program supervisi, pelaksanaan supervisi, analisis, dan tindak lanjut.

Teknik pengumpulan data pada penelitian ini terdiri atas empat kegiatan pokok yakni pengumpulan data awal, data hasil analisis setiap akhir siklus, serta tanggapan lain dari guru terhadap pelaksanaan supervisi edukatif model kolaboratif.

Data yang telah dikumpulkan dianalisis dengan menggunakan analisis kualitatif dan kuantitatif. Analisis kualitatif digunakan untuk menjelaskan perubahan perilaku guru dalam pembelajaran dan perilaku Peneliti dalam melaksanakan supervisi guru. Adapun analisis kuantitatif digunakan untuk mengetahui keberhasilan guru dan siswa berdasarkan standar kompetensi guru yang telah ditetapkan oleh Depdiknas sebagai berikut.
a. Nilai $81-100$
= amat baik (A) berhasil
b. Nilai $76-80$
$=$ baik $(\mathrm{B})$ berhasil
c. Nilai $55-75$
= cukup $(\mathrm{C})$ belum berhasil
d. Nilai $0-54$
= kurang (D) belum berhasil 


\section{HASIL PENELITIAN}

\section{Pemaparan Data Siklus ke I}

Hasil siklus pertama dapat dilihat pada tabel berikut ini

Tabel 1. Hasil Penentuan Perencanaan Siklus I

\begin{tabular}{|c|c|c|c|c|}
\hline No. & Indikator & $\begin{array}{l}\text { Jumlah } \\
\text { Guru }\end{array}$ & $\begin{array}{c}\text { JML Guru } \\
\text { Berhasil } \\
\text { (Skor } \geq 75)\end{array}$ & $\begin{array}{c}\% \\
\text { Keberhasilan }\end{array}$ \\
\hline 1 & $\begin{array}{l}\text { Mendeskripsikan Tujuan } \\
\text { Pembelajaran }\end{array}$ & 6 & 5 & 83 \\
\hline 2 & $\begin{array}{l}\text { Menentukan materi sesuai } \\
\text { dengan kompetensi } \\
\text { Mengorganisasikan materi }\end{array}$ & 6 & 5 & 83 \\
\hline 3 & $\begin{array}{l}\text { berdasarkan urutan atau } \\
\text { kelompok }\end{array}$ & 6 & 4 & 66,4 \\
\hline 4 & Mengalokasikan waktu & 6 & 6 & 100 \\
\hline 5 & $\begin{array}{l}\text { Menentukan metode } \\
\text { pembelajaran }\end{array}$ & 6 & 3 & 49,8 \\
\hline 6 & $\begin{array}{l}\text { Merancang prosedur } \\
\text { pembelajaran }\end{array}$ & 6 & 4 & 66,4 \\
\hline 7 & Menentukan media pembelajaran & 6 & 4 & 66,4 \\
\hline 8 & $\begin{array}{l}\text { Menentukan sumber belajar yang } \\
\text { sesuai (berupa buku, modul, } \\
\text { program komputer dan } \\
\text { sejenisnya) }\end{array}$ & 6 & 5 & 83 \\
\hline 9 & $\begin{array}{l}\text { Menentukan teknik penilaian } \\
\text { yang sesuai }\end{array}$ & 6 & 3 & 49,8 \\
\hline & Rata - Rata Keberhasilan & & & $71,98 \%$ \\
\hline
\end{tabular}

Tabel 2. Hasil Melaksanakan Pembelajaran Tindakan Siklus I

\begin{tabular}{llccc}
\hline No & \multicolumn{1}{c}{ Indikator } & $\begin{array}{c}\text { Jumlah } \\
\text { Guru }\end{array}$ & $\begin{array}{c}\text { JML Guru } \\
\text { Berhasil } \\
\text { (Skor } \geq 75)\end{array}$ & $\begin{array}{c}\% \\
\text { Keberhasilan }\end{array}$ \\
\hline \multirow{2}{*}{$\begin{array}{l}\text { Membuka pelajaran dengan metode } \\
\text { yang tepat }\end{array}$} & 6 & 5 & 83 \\
2 & $\begin{array}{l}\text { Menyajikan materi pelajaran secara } \\
\text { sistematis }\end{array}$ & 6 & 4 & 66,4 \\
3 & $\begin{array}{l}\text { Menerapkan metode dan prosedur } \\
\text { pembelajaran yang telah ditentukan }\end{array}$ & 6 & 4 & 66,4 \\
4 & $\begin{array}{l}\text { Mengatur kegiatan siswa di kelas } \\
5\end{array}$ & 6 & 5 & 83 \\
6 & $\begin{array}{l}\text { Menentukan media pembelajaran } \\
\text { Menggunakan sumber belajar }\end{array}$ & 6 & 4 & 66,4 \\
7 & $\begin{array}{l}\text { Memotivasi siswa dengan berbagai } \\
\text { cara yang positif }\end{array}$ & 6 & 4 & 66,4 \\
\hline
\end{tabular}




\begin{tabular}{llccc}
\hline No & \multicolumn{1}{c}{ Indikator } & $\begin{array}{c}\text { Jumlah } \\
\text { Guru }\end{array}$ & $\begin{array}{c}\text { JML Guru } \\
\text { Berhasil } \\
\text { (Skor } \geq 75)\end{array}$ & $\begin{array}{c}\% \\
\text { Keberhasilan }\end{array}$ \\
\hline $\begin{array}{l}\text { Melakukan interaksi dengan siswa } \\
8\end{array}$ & 6 & 5 & 83 \\
$\begin{array}{l}\text { menggunakan bahasa yang } \\
\text { komunikatif }\end{array}$ & 6 & 4 & 66,4 \\
$\begin{array}{l}\text { Memberikan pertanyaan dan umpan } \\
\text { balik }\end{array}$ & 6 & 4 & 66,4 \\
10 & $\begin{array}{l}\text { Menyimpulkan pembelajaran } \\
11\end{array}$ & 6 & 4 & 66,4 \\
Menggunakan waktu secara efektif & 6 & & $72,44 \%$ \\
\hline
\end{tabular}

Tabel 3. Hasil Menilai Prestasi Belajar Siklus I

\begin{tabular}{llccc}
\hline No. & \multicolumn{1}{c}{ Indikator } & $\begin{array}{c}\text { Jumlah } \\
\text { Guru }\end{array}$ & $\begin{array}{c}\text { JML Guru } \\
\text { Berhasil } \\
\text { (Skor } \geq 75)\end{array}$ & $\begin{array}{c}\% \\
\text { Keberhasilan }\end{array}$ \\
\hline 1 & Menyusun soal/perangkat penilaian & 6 & 5 & 83 \\
2 & Melaksanakan penilaian & 6 & 5 & 83 \\
3 & Memeriksa jawaban/memberi skor & 6 & 4 & 66,4 \\
4 & Menilai hasil belajar & 6 & 6 & 100 \\
5 & Mengolah hasil belajar & 6 & 4 & 66,4 \\
6 & Menganalisis hasil belajar & 6 & 4 & 66,4 \\
7 & Menyimpulkan hasil belajar & 6 & 4 & 66,4 \\
8 & Menyusun laporan hasil belajar & 6 & 6 & 100 \\
9 & Memperbaiki soal/perangkat & 6 & 6 & 100 \\
& penilaian & & & $81,3 \%$ \\
\hline
\end{tabular}

Tabel 4. Hasil Melaksnakan Tindak Lanjut Hasil Penilaian Siklus I

\begin{tabular}{clccc}
\hline No. & \multicolumn{1}{c}{ Indikator } & $\begin{array}{c}\text { Jumlah } \\
\text { Guru }\end{array}$ & $\begin{array}{c}\text { JML Guru } \\
\text { Berhasil } \\
\text { (Skor } \geq 75\end{array}$ & $\begin{array}{c}\text { \% Keber- } \\
\text { hasilan }\end{array}$ \\
\hline 1 & $\begin{array}{l}\text { Mengidentifikasi kebutuhan } \\
\text { tindak lanjut hasil penilaian }\end{array}$ & 6 & 4 & 66,4 \\
2 & $\begin{array}{l}\text { Menyusun program tindak } \\
\text { lanjut }\end{array}$ & 6 & 5 & 83 \\
3 & $\begin{array}{l}\text { Melaksanakan tindak lanjut } \\
\text { Mengevaluasi hasil tindak }\end{array}$ & 6 & 3 & 49,8 \\
& $\begin{array}{l}\text { lanjut hasil penilaian } \\
\text { Menganalisis hasil evaluasi } \\
\text { program tindak lanjut hasil }\end{array}$ & 6 & 3 & 49,8 \\
\hline
\end{tabular}




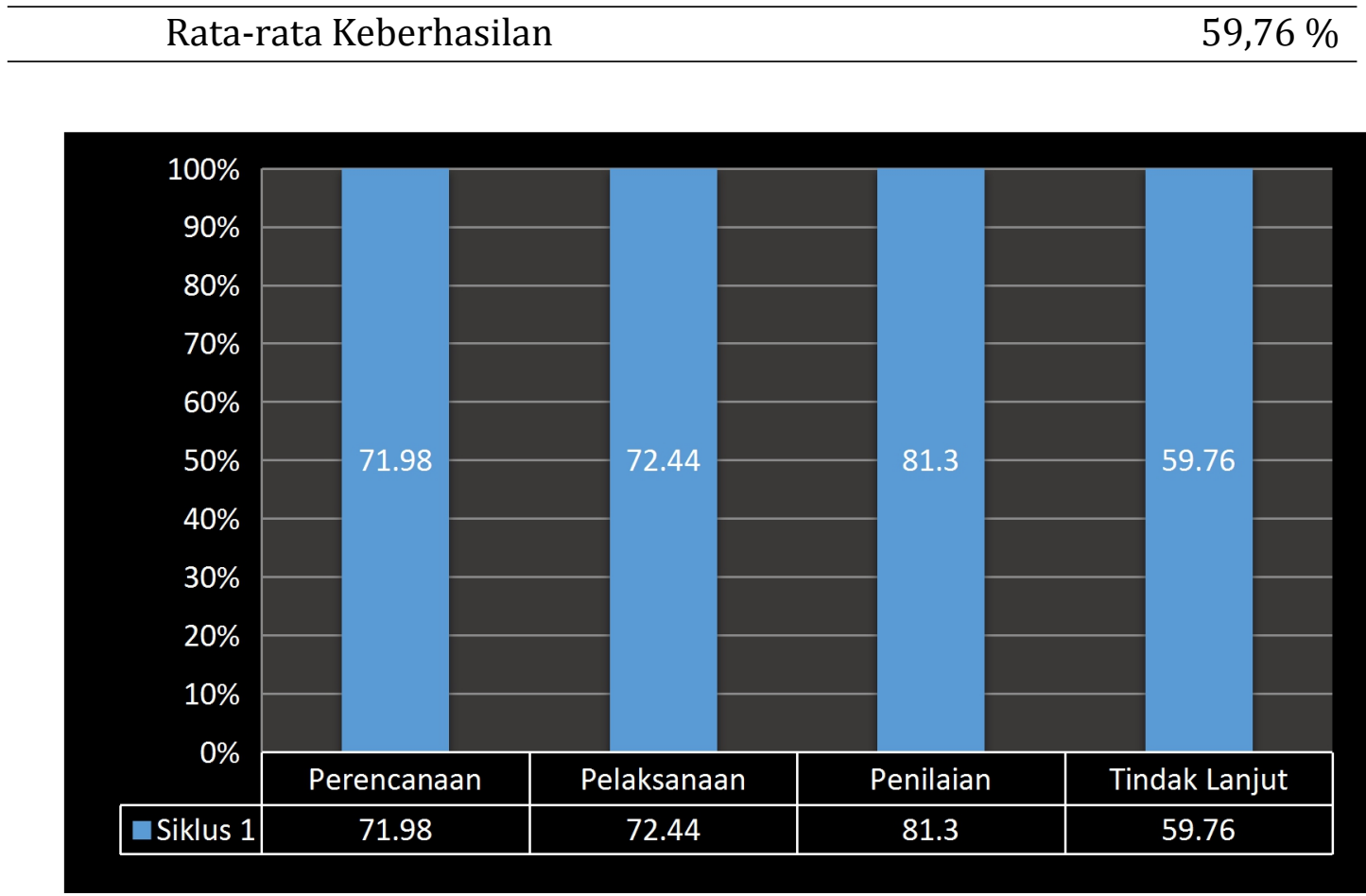

Gambar 1. Persentasi Keberhasilan Siklus I

Pada bagian penilaian ini guru berdiskusi dengan guru lain untuk menentukan tindak lanjut penilaian karena banyak bagian yang belum dipahami oleh guru-guru SDN 3 Palam. Untuk itu, ada beberapa rekomendasi yang perlu ditindaklanjuti pada siklus II yaitu: para guru SDN 3 Palam perlu workshop tentang tindak lanjut penilaian, untuk membicarakan: (a) identifikasi tindak lanjut hasil penilaian, (b) menyusun program tindak lanjut, (c)Melaksanakan tindak lanjut, (d) mengevaluasi hasil tindak lanjut, (e) menganalisis hasil evaluasi program tindak lanjut hasil penilaian.

\section{Pemaparan Data Siklus ke II}

Hasil siklus pertama dapat dilihat pada tabel berikut ini

Tabel 5. Hasil Penentuan Perencanaan Siklus II

\begin{tabular}{|c|c|c|c|c|}
\hline No. & Indikator & $\begin{array}{l}\text { Jumlah } \\
\text { Guru }\end{array}$ & $\begin{array}{c}\text { JML Guru } \\
\text { Berhasil } \\
\text { (Skor } \geq 75 \text { ) }\end{array}$ & $\begin{array}{c}\% \\
\text { Keberhasilan }\end{array}$ \\
\hline 1 & $\begin{array}{l}\text { Mendeskripsikan Tujuan } \\
\text { Pembelajaran }\end{array}$ & 6 & 6 & 100 \\
\hline 2 & $\begin{array}{l}\text { Menentukan materi sesuai dengan } \\
\text { kompetensi }\end{array}$ & 6 & 6 & 100 \\
\hline 3 & $\begin{array}{l}\text { Mengorganisasikan materi } \\
\text { berdasarkan urutan atau kelompok }\end{array}$ & 6 & 5 & 83 \\
\hline 4 & Mengalokasikan waktu & 6 & 6 & 100 \\
\hline 5 & Menentukan metode pembelajaran & 6 & 5 & 83 \\
\hline 6 & Merancang prosedur pembelajaran & 6 & 5 & 83 \\
\hline
\end{tabular}




\begin{tabular}{lllll}
\hline 7 & $\begin{array}{l}\text { Menentukan media pembelajaran } \\
\text { Menentukan sumber belajar yang }\end{array}$ & 6 & 5 & 83 \\
8 & $\begin{array}{l}\text { sesuai (berupa buku, modul, } \\
\text { program komputer dan sejenisnya) }\end{array}$ & 6 & 6 & 100 \\
9 & $\begin{array}{l}\text { Menentukan teknik penilaian yang } \\
\text { sesuai } \\
\text { Rata - Rata Keberhasilan }\end{array}$ & 6 & 6 & 100 \\
\hline
\end{tabular}

Tabel 6. Hasil Melaksanakan Pembelajaran Tindakan Siklus II

\begin{tabular}{|c|c|c|c|c|}
\hline No. & Indikator & $\begin{array}{l}\text { Jumlah } \\
\text { Guru }\end{array}$ & $\begin{array}{c}\text { JML Guru } \\
\text { Berhasil } \\
\text { (Skor } \geq 75 \text { ) }\end{array}$ & $\begin{array}{c}\% \\
\text { Keberhasilan }\end{array}$ \\
\hline 1 & $\begin{array}{l}\text { Membuka pelajaran dengan metode } \\
\text { yang tepat }\end{array}$ & 6 & 6 & 100 \\
\hline 2 & $\begin{array}{l}\text { Menyajikan materi pelajaran secara } \\
\text { sistematis }\end{array}$ & 6 & 5 & 83 \\
\hline 3 & $\begin{array}{l}\text { Menerapkan metode dan prosedur } \\
\text { pembelajaran yang telah ditentukan }\end{array}$ & 6 & 5 & 83 \\
\hline 4 & Mengatur kegiatan siswa di kelas & 6 & 6 & 100 \\
\hline 5 & Menentukan media pembelajaran & 6 & 5 & 83 \\
\hline 6 & Menggunakan sumber belajar & 6 & 6 & 100 \\
\hline 7 & $\begin{array}{l}\text { Memotivasi siswa dengan berbagai } \\
\text { cara yang positif }\end{array}$ & 6 & 6 & 100 \\
\hline 8 & $\begin{array}{l}\text { Melakukan interaksi dengan siswa } \\
\text { menggunakan bahasa yang } \\
\text { komunikatif }\end{array}$ & 6 & 6 & 100 \\
\hline 9 & $\begin{array}{l}\text { Memberikan pertanyaan dan umpan } \\
\text { balik }\end{array}$ & 6 & 5 & 83 \\
\hline 10 & Menyimpulkan pembelajaran & 6 & 6 & 100 \\
\hline 11 & $\begin{array}{l}\text { Menggunakan waktu secara efektif } \\
\text { Rata - Rata Keberhasilan }\end{array}$ & 6 & $\begin{array}{l}6 \\
93,81 \%\end{array}$ & 100 \\
\hline
\end{tabular}

Tabel 7. Hasil Menilai Prestasi Belajar Siklus II

\begin{tabular}{llccc}
\hline No. & \multicolumn{1}{c}{ Indikator } & $\begin{array}{c}\text { Jumlah } \\
\text { Guru }\end{array}$ & $\begin{array}{c}\text { JML Guru } \\
\text { Berhasil } \\
\text { (Skor } \geq 75)\end{array}$ & $\begin{array}{c}\% \\
\text { Keberhasilan }\end{array}$ \\
\hline 1 & Menyusun soal/perangkat penilaian & 6 & 5 & 83 \\
2 & Melaksanakan penilaian & 6 & 5 & 83 \\
3 & Memeriksa jawaban/memberi skor & 6 & 5 & 83 \\
4 & Menilai hasil belajar & 6 & 6 & 100 \\
5 & Mengolah hasil belajar & 6 & 6 & 100 \\
6 & Menganalisis hasil belajar & 6 & 5 & 83 \\
7 & Menyimpulkan hasil belajar & 6 & 5 & 83 \\
\hline
\end{tabular}




\begin{tabular}{|c|c|c|c|c|}
\hline 8 & Menyusun laporan hasil belajar & 6 & 6 & 100 \\
\hline \multirow[t]{2}{*}{9} & $\begin{array}{l}\text { Memperbaiki soal/perangkat } \\
\text { penilaian }\end{array}$ & 6 & \multirow[t]{2}{*}{6} & 100 \\
\hline & Rata - Rata Keberhasilan & & & $90.56 \%$ \\
\hline \multicolumn{5}{|c|}{ Tabel 8. Hasil Melaksnakan Tindak Lanjut Hasil Penilaian Siklus II } \\
\hline No. & Indikator & $\begin{array}{l}\text { Jumlah } \\
\text { Guru }\end{array}$ & $\begin{array}{c}\text { JML Guru } \\
\text { Berhasil } \\
\text { (Skor } \geq 75)\end{array}$ & $\begin{array}{c}\% \\
\text { Keberhasilan }\end{array}$ \\
\hline 1 & $\begin{array}{l}\text { Mengidentifikasi kebutuhan tindak } \\
\text { lanjut hasil penilaian }\end{array}$ & 6 & 5 & 83 \\
\hline 2 & Menyusun program tindak lanjut & 6 & 5 & 83 \\
\hline 3 & Melaksanakan tindak lanjut & 6 & 5 & 83 \\
\hline 4 & $\begin{array}{l}\text { Mengevaluasi hasil tindak lanjut } \\
\text { hasil penilaian }\end{array}$ & 6 & 5 & 83 \\
\hline \multirow[t]{2}{*}{5} & $\begin{array}{l}\text { Menganalisis hasil evaluasi program } \\
\text { tindak lanjut hasil penilaian }\end{array}$ & 6 & 5 & 83 \\
\hline & Rata-rata Keberhasilan & & & $83 \%$ \\
\hline
\end{tabular}

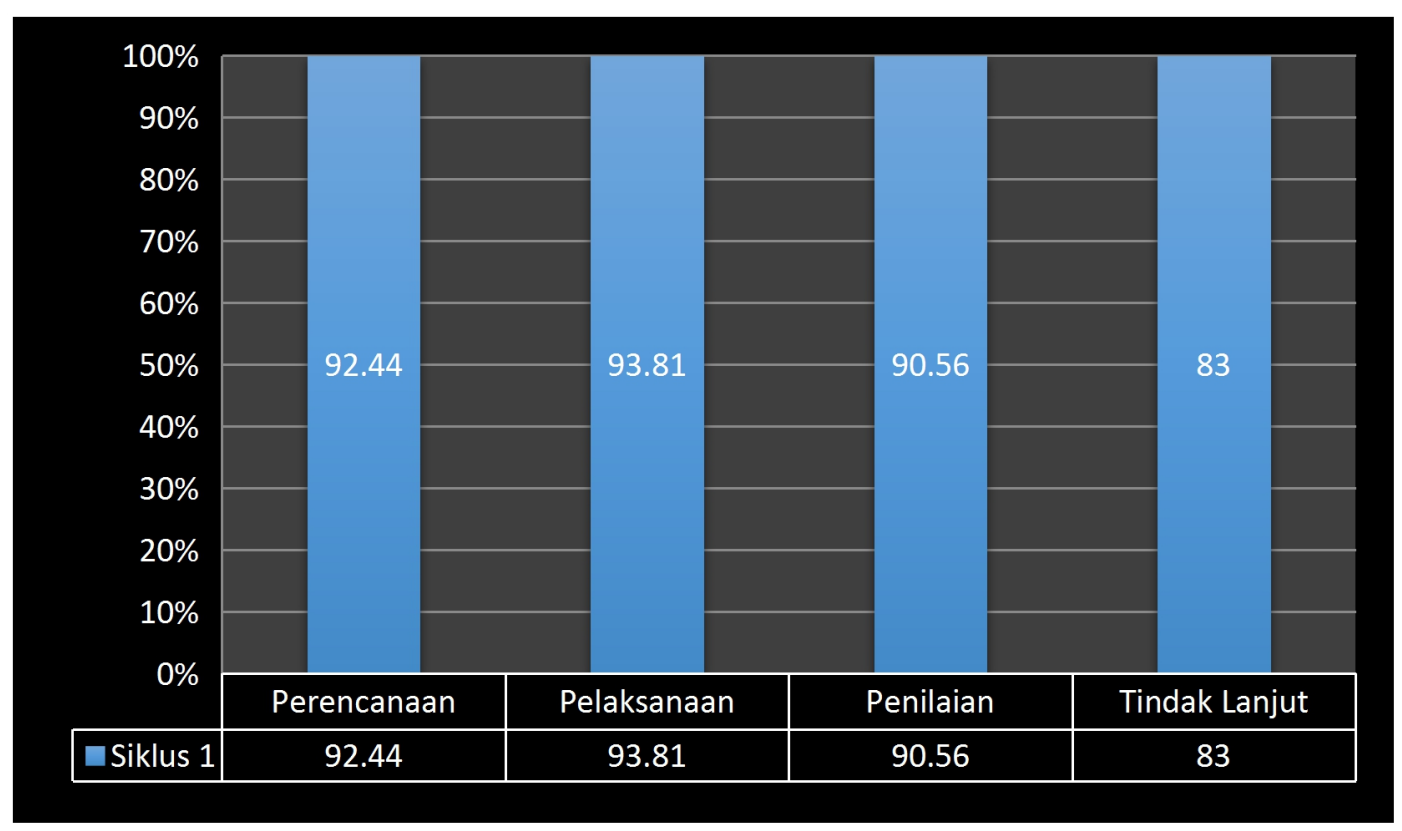

Gambar 2. Persentasi Keberhasilan Siklus II 


\section{Perbandingan Data Setiap Siklus}

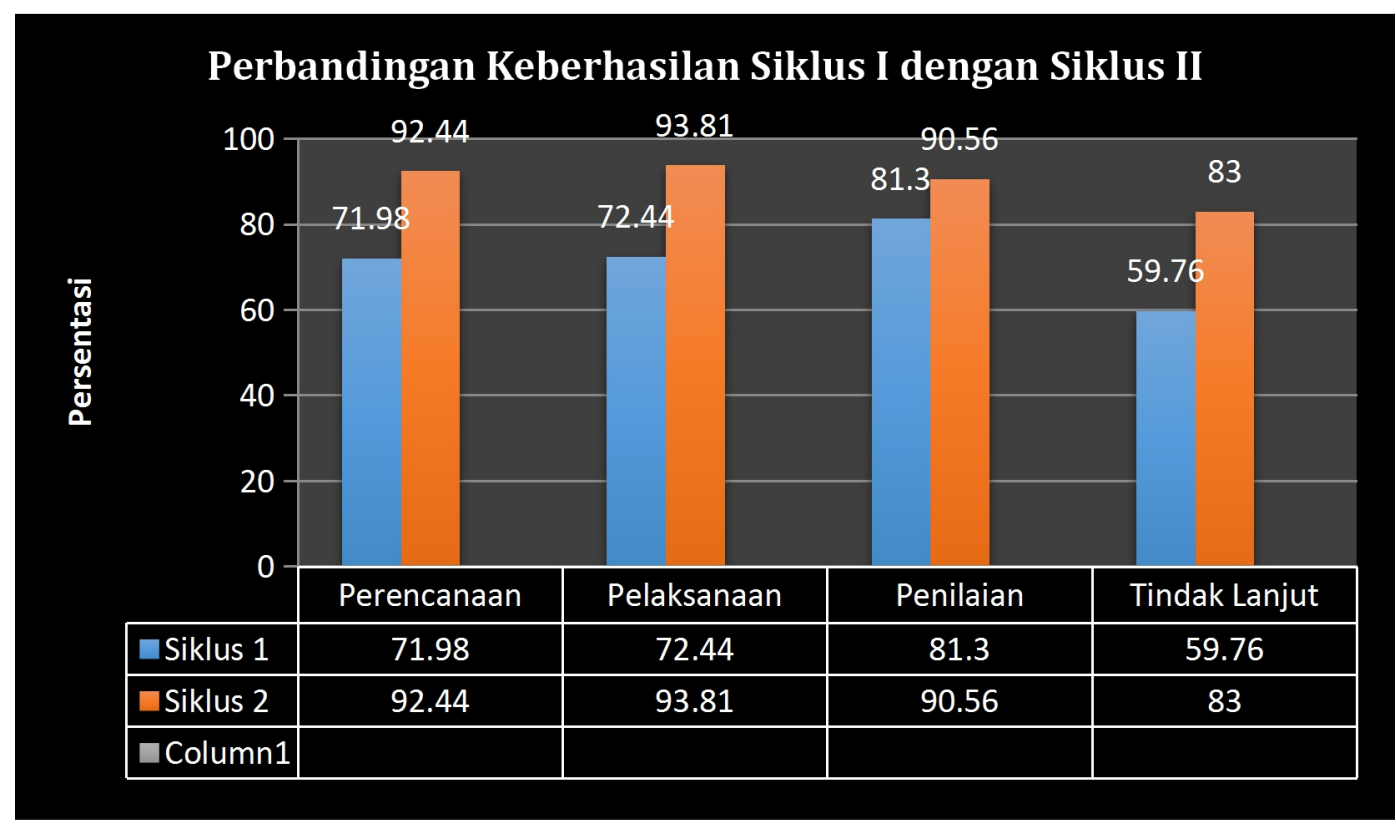

Gambar 3. Perbandingan Keberhasilan Siklus I dengan Siklus II

\section{PEMBAHASAN}

Pembahasan didasarkan pada teori-teori yang sudah ada, baik berdasarkan pada referensi mapun dari ucapan ahli di bidang penelitian ini. Adapun pembahasan hasil penelitian ini sebagai berikut.

Temuan pertama, kinerja guru meningkat dalam membuat perencanaan pembelajaran. Hal ini terjadi karena adanya kerja sama antara guru kelas yang satu dengan lainnya serta diberi pengarahan oleh peneliti. Langkah-langkah yang dapat meningkatkan kinerja guru dalam membuat persiapan pembelajaran adalah: (1) Peneliti memberikan format supervisi dan jadwal supervisi pada awal tahun pelajaran atau awal semester. Pelaksanaan supervisi tidak hanya dilakukan sekali, (2) Peneliti selalu menanyakan perkembangan pembuatan perangkat pembelajaran (mengingatkan betapa pentingnya perangkat pembelajaran), (3) satu minggu sebelum pelaksanaan supervisi perangkat pembelajaran, Peneliti menanyakan format penilaian, jika format yang diberikan pada awal tahun pelajaran tersebut hilang, maka guru yang bersangkutan disuruh memfotokopi arsip sekolah. Jika di sekolah masih banyak format seperti itu maka guru tersebut diberi kembali. Bersamaan dengan memberi/menanyakan format, Peneliti meminta pengumpulan perangkat pembelajaran yang sudah dibuatnya untuk untuk diteliti kelebihan dan kekurangannya, (4) Peneliti memberikan catatan-catatan khusus pada lembaran untuk diberikan kepada guru yang akan disupervisi tersebut. (5) Peneliti dalam menilai perangkat pembelajaran penuh perhatian dan tidak mencerminkan sebagai penilai. Peneliti bertindak sebagai kolaborasi. Peneliti membimbing, mengarahkan guru yang belum bisa, tetapi Peneliti juga menerima argumen guru yang positif. Dengan adanya itu, terciptalah hubungan yang akrap antara guru dan Peneliti. Tentu saja ini akan membawa nilai positif dalam pelaksanaan pembelajaran. 
Temuan kedua, kinerja guru meningkat dalam melaksanakan pembelajaran. Dalam penelitian tindakan ini ternyata dari 6 guru hampir semuanya mampu melaksanakan pembelajaran dengan baik. Hal ini terbukti dari hasil supervisi. Langkah-langkah yang dilakukan untuk meningkatkan pelaksanaan pembelajaran berdasarkan penelitian tindakan ini adalah: (1) Peneliti yang mengamati guru mengajar tidak sebagai penilai tetapi sebagai rekan bekerja yang siap membantu guru tersebut, (2) Selama pelaksaaan supervisi di di kelas guru tidak menganggap Peneliti sebagai penilai karena sebelum pelaksanaan supervisi guru dan Peneliti telah berdiskusi permasalahan-permasalahan yang ada dalam pembelajaran tersebut, (3) Peneliti mencatat semua peristiwa yang terjadi di dalam pembelajaran baik yang positif maupun yang negatif, (4) Peneliti selalu memberi contoh pembelajaran yang berorientasi pada Modern Learning. (5) Jika ada guru yang pembelajarannya kurang jelas tujuan, penyajian, umpan balik, Peneliti memberikan contoh bagaimana menjelaskan tujuan, menyajikan, memberi umpan balik kepada guru tersebut, (6) Setelah guru diberi contoh pembelajaran modern, Peneliti setiap dua atau tiga minggu mengunjungi atau mengikuti guru tersebut dalam proses pembelajaran.

Temuan ketiga, kinerja guru meningkat dalam menilai prestasi belajar siswa. Pada penelitian tindakan yang dilakukan di SDN 3 Palam ini ternyata pelaksanaan supervisi edukatif kolaboratif secara periodik memberikan dampak positif terhadap guru dalam menyusun soal/perangkat penilaian, melaksanakan, memeriksa, menilai, mengolah, menganalisis, menyimpulkan, menyusun laporan dan memperbaiki soal. Sebelum diadakan supervisi edukatif secara kolaboratif, guru banyak yang mengalami kesulitan dalam melaksankan penilaian. Langkah-langkah yang dilakukan dalam supervisi edukatif kolaboratif secara periodik yang dapat meningkatkan kinerja guru adalah: (1) Peneliti berdiskusi dengan guru dalam pembuatan perangkat penilaian sebelum dilaksanakan supervisi, (2) Guru melaksanakan penilaian sesuai dengan aturan yang telah ditetapkan bersama Peneliti yang sebagai kolaboratif dalam pembelajaran, (3) Guru membuat kriteria penilaian yang berkaitan dengan penskoran, pembobotan, dan pengolahan nilai, yang sebelum pelaksanaan supervisi didiskusikan dengan peneliti, (4) Guru menganalisis hasil penilaian dan melaporkannya kepada urusan kurikulum.

Temuan keempat, Kinerja guru meningkat dalam melaksanakan tindak lanjut hasil penilaian prestasi belajar peserta didik. Langkah-langkah yang dapat meningkatkan kinerja guru dalam supervisi edukatif kolaboratif adalah: (1) Peneliti dan guru bersama-sama membuat program tindak lanjut hasil penilaian, (2) Peneliti memberi contoh pelaksanaan tindak lanjut, yang akhirnya dilanjutkan oleh guru dalam pelaksanaan yang sebenarnya, (3) Peneliti mengajak diskusi pada guru yang telah membuat, melaksanakan, dan menganalis program tindak lanjut.

Temuan kelima, Kinerja guru meningkat dalam menyusun program pembelajaran, melaksanakan pembelajaran, menilai prestasi belajar, dan melaksanakan tindak lanjut hasil prestasi belajar siswa.

\section{SIMPULAN}

Berdasarkan temuan hasil penelitian ada empat hal yang dikemukakan dalam penelitian tindakan ini, yakni simpulan tentang: Peningkatan kinerja guru dalam menyusun 
rencana pembelajaran. Peningkatan kinerja guru dalam melaksanakan pembelajaran. Peningkatan kinerja guru dalam menilai prestasi belajar. Peningkatan kinerja guru dalam melaksanakan tindak lanjut hasil penilaian prestasi belajar siswa. Berdasarkan peningkatan kinerja guru baik rencana pembelajaran, pelaksanaan pembelajaran, penilaian hasil belajar, dan pelaksanaan tindak lanjut hasil penilaian siswa ternyata mempengaruhi hasil ujian siswa tahun 2020.

\section{DAFTAR PUSTAKA}

Departemen Pendidikan Nasional. 2003. Undang-Undang RI No.20 Tahun 2003. Tentang Sistem Pendidikan Nasional.

Departemen Pendidikan Nasional. 2004. Manajemen Berbasis Sekolah. Jakarta: Direktorat Jenderal Manajemen Pendidikan Dasar dan Menengah Direktorat Pembinaan Sekolah Menengah Pertama.

Diknas. 2006. Undang-Undang Guru dan Dosen, Yokyakarta: Pustaka Pelajar.

Diknas. 2005. Undang-undang Repiblik Indonesia No. 20 Tentang Sistem Pendidikan Nasional: Jakarta.

Mashud, M. (2015). Pendekatan Pembelajaran Pendidikan Jasmani Olahraga dan Kesehatan di Era Abad 21. Jurnal Multilateral, 14(2), 89-196. https://doi.org/10.20527/multilateral.v14i2.2471.g2172

Saondi, O., Suherman, A. 2010. Etika Profesi Keguruan. Bandung: Aditama.

Syamsuddin, A. 2005. Psikologi Pendidikan. Bandung: PT. Remaja Rosdakarya. 